\title{
Notes on Calvin's knowledge, use, and misuse of the Church Fathers
}

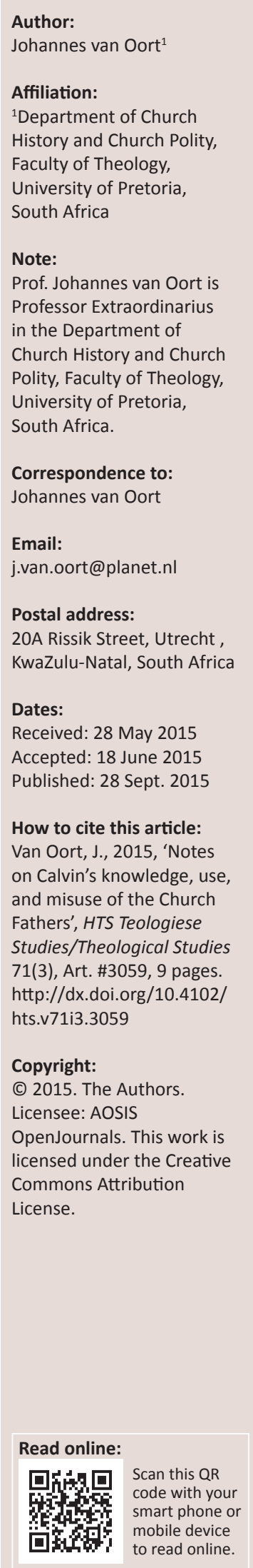

John Calvin (1509-1564) started his career as a thoroughly trained humanist who possessed, in addition, a thorough knowledge of the Fathers of the Church. This article provides an overview of this particular knowledge. It also focuses on the use Calvin made of the patristic argument in both his instructive and apologetic writings. Some evident cases of Calvin's misuse of the patres are discussed as well. It is concluded that Calvin's special patristic knowledge gave his theology its special hallmark and still links authentic Calvinism with the church's catholic tradition through the ages.

\section{The state of research}

The subject theme 'Calvin and the Church Fathers' is a broad one. Those familiar with it will agree that a few pages cannot provide an exhaustive account. For this reason I limit myself to a number of notes on the main issues ${ }^{1}$ while a few other questions and problem areas will be touched upon which, as far as I can see, deserve further investigation.

Firstly, some remarks on the state of research on the subject. Calvin completed no official university study on the patres, but nevertheless displayed an excellent knowledge of the topic. This specialist knowledge has been pointed out by a number of researchers. Foremost is the magisterial work by Luchesius Smits (1956-1958) on Augustine in the (whole!) auvre of Calvin. ${ }^{2}$ Smits convincingly illustrated Calvin's extensive and impressively deep knowledge of the North African Church Father. While the theme of Calvin's acquaintance with Augustine was also addressed in a number of smaller studies, ${ }^{3}$ virtually all subsequent researchers are indebted to the foundational work of Smits. After him, the most comprehensive study on the relation between Calvin and Augustine has been the doctoral dissertation by Marius Lange van Ravenswaaij (1990). He analysed the essential agreements in both theologians' doctrine of predestination, while also noting several differences. That Calvin would be the initiator of a new 'schola Augustiniana' seems unproven, however (cf. Van Oort 1992:92-103).

R.J. Mooi's doctoral dissertation (1965) attempted a treatment of the entire patristic (and even part of the medieval) background of Calvin. This study is profound and still serves as an important reference work, although one may sometimes disagree on the details. ${ }^{4}$ Mooi's dissertation, completed in 1965, did not mention William Todd's thesis on the function of the patristic writings in Calvin (1964). While both dissertations came to similar conclusions, Mooi's study reveals greater depth and covers a broader spectrum. Anyone who has not only read this work, but also used the rich treasures of information contained in its tables, will not have found much that is new in John Walchenbach's dissertation on Calvin and Chrysostomus (1974). Walchenbach was clearly not aware of Mooi's study, and apart from this presented a rather superficial work. It is also disappointing that Alexandre Ganoczy and Klaus Müller, who in 1981 published Calvin's handwritten annotations to a tripartite edition of Chrysostom from 1536, ${ }^{5}$ seem to have been ignorant of not only Mooi's extensive contribution, but also that of Walchenbach and Todd (1964). A sound contribution has been provided by Anette Zillenbiller on Calvin's reception of Cyprian (1993). According to this self-professed Roman Catholic scholar, Calvin awarded a special meaning to Cyprian's testimony. In her clear and

1.Earlier I wrote a more comprehensive overview of the subject in Van Oort ([1997] 2001:661-700). In the present article my focus is on Calvin's use and (some cases of evident) misuse.

2.This work was initially a dissertation to obtain a Magister degree at the Catholic University of Leuven in Belgium.

3.Cf. the chronological summary of Lane (1981:149-205).

4.This primarily concerns the listed numbers which often are no longer correct. Moreover, Mooi is sometimes led astray by (incorrect) references provided by the editors of the five volumes of selected works of Calvin in the Opera Selecta (henceforth: OS) and the 55 volumes of Opera Calvini (henceforth: OC) in the series Corpus Reformatorum (henceforth: CR). Thus arises, for instance, the 55 volumes of Opera Calvini (henceforth: $O C$ ) in the series Corpus Reformatorum (henceforth
impression that Calvin cites Duns Scotus in his Inst. of 1539, which is, however, not the case.

5.The same goes for the fine introduction with translation with full commentary provided by Hazlett (1991:129-150). On the topic, see also Awad (2010:414-436). 
carefully considered dissertation, she provides her opinion of not only Todd, but also Smits and Mooi, while actualising both Cyprian and Calvin in an interesting manner in light of Vatican II. The painstaking work of Anthony Lane entitled John Calvin: Student of the Church Fathers (1999) may be considered to be, after Smits and Mooi, another pinnacle in the field of research. Lane's book is to a considerable extent, based on topical articles he published earlier (cf. Lane 1999:xii and below). As its title already indicates, the dissertation by Esther Chung-Kim (2011) only partially deals with Calvin: she concentrates on his use of the fathers in his commentaries and Institution, and also deals with the Eucharistic debates between Calvin and Joachim Westphal and Tilemann Hesshusen, respectively.

So far I have mentioned studies about Calvin and the Church Fathers which appeared in book form. They comprise a considerable amount of highly relevant research. Much on the theme has also been published in diverse books on (aspects of) Calvin's life and theology. ${ }^{6}$ Dedicated in its entirety to the subject, and certainly of special significance, was Tony Lane's article on 'Calvin's use of the Fathers and the Medievals' (1981:149-205). In Appendix I, Lane provided a nearly complete bibliography of books and articles on the theme, published up to 1980. Of the studies published after that date, the short contribution by Irena Backus (1991:419437) about Calvin and Eusebius deserves special mention. ${ }^{7}$ In her 1991 study, Backus comes to the same conclusions that Lane had previously formulated as follows (Lane 1981:190; cf. Backus 1991:437):

1. Calvin appears wonderfully accurate in his knowledge and use of the Fathers on the one hand, but highly selective on the other.

2. Calvin's use of the Fathers is an impressive attempt to relate 16th century Protestantism with the church of the first centuries.

\section{The patristic element in Calvin}

Let us firstly consider some key moments of Calvin's concern, following, as far as possible, the historical order. Hence, we start with the young Calvin. There seems to be a development in his thinking, leading on the one hand to a few highlights, but on the other hand revealing a critical element as well. While Calvin harboured great appreciation for the Fathers, he did not spare them his sometimes harsh criticism.

\section{The Commentary on Seneca (1532)}

In his Commentary on Seneca's De Clementia, completed in March 1531 and published in early April 1532, we hear the

6.l only mention here the "historical' sections in Dankbaar (1941); Meijering (1980); Old (1975); and from more recent times, Baars (2004). The Louvain Magister thesis by Polman (1932) is still of particular importance. See, for example pages 65-99, where Polman focuses on Calvin's use of the church fathers.

7.Also relevant: Lane (1976:253-283) and some of his later studies (some in revised form in Lane (1999:87-150) and Raitt (1981:98-121); other important material in Fischer (1986:79-125). A general but incomplete overview has been provided by, for example Boisset 1988:39-51). For other studies, see for example Lane (1981). From the most recent and relevant studies I only mention here Seebach (2011:75-98). young humanist. ${ }^{8}$ Barely 22 years of age, has Calvin accepted the great Erasmus's challenge to write his own commentary on the work of Seneca. Calvin's knowledge of the classics is impressive, but his acquaintance with the Church Fathers appears to be scarce. While he mentions Cyprian, Lactantius, Jerome and Gregory the Great, these are most likely secondhand references. Calvin's knowledge and use of Augustine is however, an exception: This Church Father is cited 20 times, and 15 times the quotations come from his On the City of God. There is some reason to suppose that he looked through and perhaps read - the famous humanistic commentary of Juan Luis Vives ${ }^{9}$ This could be done fairly easily, since the 'opus absolutissimum', accompanied by Vives's commentary, was published by Froben in Basle in 1522. These quotes do not have theological significance, however their goal was humanistic scholarly illustration.

\section{The 'Praefatio' to the Neuchâtel Bible (1535)}

A completely different picture already emerges from the Latin 'Preface' that Calvin wrote in 1535 for the French Bible translation by his cousin Robert Olivétan (CO 9, 787-790). More than once he not only refers to, but explicitly appeals to the Fathers. Calvin relates how Jerome wanted to do Bible study, they say, even [...] with women. Chrysostomus and Augustine urged repeatedly that the scripture heard in church should be reread at home; Jerome praised Pamphilus for his good codices, et cetera. It is especially the references to Chrysostomus and Augustine in this 'Praefatio' that draw our attention. Evidently, it is here about citations with theological meaning.

\section{The First Institution (1536) and the Letter to King Francis I (1535)}

We encounter a similar emphasis on citations with theological significance in Calvin's famous letter to King Francis I, preceding the first edition of his Institution..$^{10}$ This 'Praefatio ad christianissimum regem Franciae', dated 23 August 1535, is distinguished by its apologetic and even polemical use of the Fathers. Over against the accusation of the opponents that the Protestant doctrines would be 'new' and 'of recent birth' ('novam et nuper natam', accusations which were also heard in the humanist circle around Guillaume Budé), and against their appeal to the Fathers, Calvin states two things. Firstly, the teachings of Rome are contrary to the teaching of the Early Church. Secondly, Protestant doctrine is in fact closest to that of the Fathers. 'If the battle were to be decided by the authority of the fathers, the victory would be

8.See, for example the Utrecht dissertation by Hugo (1957), and the text edition, with excellent explanations, by Battles and Hugo (1969). Also of value: Battles (1966:3866; also in Battles 1996:65-89).

9.Cf. for example Battles (1966:41, 63-66 [Appendix I]); Battles and Hugo (1969:132*); cf. Smits vol. I (1956-1958:16).

10.In the English-speaking world it has become practice to speak of Calvin's Institutes instead of Institution. See, for example the introduction to McNeill and Battles (1960:xxxi, n. 3). I see no sound (historical) reason to follow this practice. 
largely in our favour' (OS I, 27). ${ }^{11}$ Having illustrated, rather polemically, how even the 'Fathers' could disagree, Calvin lists a series of patristic testimonials that verify the Reformed position. (Pseudo) Chrysostom ${ }^{12}$ denies that 'the sacrament of the meal' (sacramentum coenae, i.e., Holy Eucharist) is the true body of Christ, and stresses that the 'mysterium corporis', that is, the mystical union with Christ is what really matters; both from Gelasius (through the Decretum Gratiani) and from Cyprian it appears that the celebration of the Lord's Supper took place under two forms: bread and wine for the people. Augustine warned about the audacity of prescribing something or capturing something 'without clear and evident witnesses from Scripture'; et cetera. In accordance with Cyprian it should be said that one should not follow custom (consuetudo), but must listen to Christ alone. 'All the fathers with one heart have abhorred and with one voice have detested the fact that the holy Word of God has been defiled by the subtleties of the sophists and involved in the squabbles of the dialecticians'(OS I, 29). ${ }^{13}$

Noteworthy in this Letter to Francis I, which simultaneously functions as official preface of the work, is the certain ease with which the then 26-year-old argues his case. Several of these testimonies - including (for us) rather strange historical references, for example to a certain Acatius $^{14}$ and a certain Spiridion ${ }^{15}$ - return again later, even after several years. Acatius is still found in the Institutes of 1559 (which in itself does not say very much, given the expanding nature of this work), but also in the Commentary on the Five Books of Moses of 1563. One might ask whether Calvin had all these texts and authors in his memory, or whether he had constructed some notebook, in which he listed his testimonials from the Fathers and church historians, such as Eusebius (Historia Ecclesiastica) and Cassiodorus (Historia Tripartita)? This seems to be a sensible question to consider, and we will do so shortly.

The aforementioned dual argument (firstly, we do not teach new things, but are in agreement with the Early Church; secondly, it is in fact Rome that has introduced a variety of novelties) is also laid out at length in the first Institution. As is well known, the publication of this Institution served a dual purpose, which is also maintained more or less clearly in the later editions (Obendiek 1936:417-431). On the one hand, it was meant to serve as a catechetical instruction, as a pietatis summa for the Protestants. On the other hand (and then especially the fifth chapter: De falsis sacramentis), it takes on the nature of an apology. ${ }^{16}$ It is, not coincidentally,

11.... Patres opponunt ... quorum autoritate si dirimendum certamen esset, melior victoriae pars ad nos inclinaret.'

12.As Calvin quite accurately mentions (OS I, 28): the 'Autor operis imperfecti in Matthaeum. Homil. 11. est inter opera Chrysost.'

13.'Patres omnes uno pectore execrati sunt, et uno ore detestati sanctum Dei verbum sophistarum argutiis contaminari, et dialecticorum rixis implicari.'

14.That is, Akakios, Bishop of Amida, presently Amadija or Diarbekir, in the northern basin of the Tigris.

15.That is, Spyridon, in the 4th century bishop of Trimithus, a city of Cyprus.

16.I can't help but to see here a striking parallel with Augustine's De civitate Dei, the very first patristic writing that Calvin appears to have studied thoroughly. On De civitate Dei as being both an apology and a catechetical instruction, see Van Oor (1991:164-198). - As is well known, the title of Calvin's Institutio may have been precisely in the fifth chapter that the patristic element is most prominent.

Still, it is worth going into a brief examination of those testimonials that Calvin adduces from the beginning of his work. In this way, one discovers both his knowledge of and his method of using the Fathers.

The first chapter, 'On the Law' (De lege), contains five citations and each of them appears in a characteristic context. The Decalogue, for Calvin, is to be divided into four and six commandments; this is nothing new, for Origen already knew this division and he lived in a 'purer age' (puriore saeculo). Augustine's division was indeed slightly different (three and seven), yet this was for the rather frivolous reason of highlighting the mystery of the Trinity in the first three Commandments. Besides, Calvin, with regard to content, sees no substantial difference with his own division: this one would please Augustine even more! (OS I, 49). ${ }^{17} \mathrm{He}$ also finds himself in agreement with the author of the Unfinished Work on Matthew (i.e. Pseudo-Chrysostomus).

A perusal of these three citations indicated by Calvin himself reveals great precision. The correction introduced by Petrus Barth in his edition (OS I, 49 n. 20) where, instead of referring to Augustine, he refers to Ambrosiaster (Quaestiones Veteris et Novi Testamenti), seems incorrect. The original first edition of the Institution shows the correct reference to Augustine in the margin, 'Quaestiones in Hept., lib. $\mathrm{II}^{\prime} .^{18}$ These three citations clearly have the apologetical-theological purpose of making plain that Calvin is no modernist. This will also be the reason why, from the second edition of 1539 onwards, these passages were considerably extended with references to Augustine.

A few pages further, another apologetic-theological purpose appears. For Calvin, our salvation consists entirely of God's mercy (misericordia), and not of any worthiness (dignitas) of our own. It is therefore misguided to trust in good works. A citation from Augustine confirms this: 'Forgetting our merits, we embrace Christ's gifts' (OS I, 60). ${ }^{19}$ Calvin often returns to this quotation, and it is most likely the fruit of his independent reading of Augustine's sermons. It does not appear, in any case, in common textbooks such as Lombardus' Sententiae or the Decretum Gratiani, ${ }^{20}$ works that the young Calvin sometimes used as sources. Until now I have not found it in the writings of earlier contemporaries

chosen after the example of the Divinae Institutiones of Lactantius, the 'father' who in humanists' circles was venerated as 'the Christian Cicero'. For other possibilities see for example the introduction to McNeill and Battles (1960:xxxi, n. 3).

$17 . .$. in caeteris nostra [sc. divisio] magis ei placebat.'

18.I could consult one of the copies which survived worldwide in the library of Utrecht University. For this edition and other surviving copies, see also Peter and Gilmont (1991:35-36). As far as I know, the Utrecht copy is the only original edition available in the Netherlands. My impression is that a renewed careful study of both the Latin text and the margins may still be fruitful.

19.'nostra merita obliti, Christi dona amplectimur', Aug., De verbis apostoli 11 (= now sermo 174,2).

20.Magistri Petri Lombardi Sententiae in IV libris distinctae (1971-1981); Corpus iuris canonici [1879] 1959. 
such as Bucer or Melanchthon, and not even in Luther. ${ }^{21} \mathrm{~A}$ maxim that almost everyone knew - the well-known saying 'Give what You command and command what You will' from Augustine's Confessions ${ }^{22}$ - is woven into Calvin's argument without reference to a source and even without mentioning Augustine's name (OS I, 55).

One may find more patristic reminiscences in the first chapter of the first Institution (see, e.g. Battles [1986] 1989:243-252), but the just mentioned examples are the explicit references. Interestingly, patristic references are lacking in the following two chapters 'On Faith' (De fide) and 'On Prayer' (De oratione). It is only said - as a kind of polemical illustration of Calvin's rejection of the idea that the Christian saints would have a mediating function in prayer - that Ambrose calls Christ 'the mouth through which we speak to the Father, the eye whereby we see the Father, the right hand through which we offer ourselves to the Father' (OS I, 100). ${ }^{23}$

The following two chapters, however, contain many patristic citations. A brief analysis may indicate where the centre of gravity lay for both the earlier and later Calvin. In chapter four he outlines the typically reformed approach to the sacraments, an approach which he also feels compelled to defend, especially against Roman Catholic opponents. His reference to the Fathers in this context is noteworthy. He appeals to them explicitly no less that 14 times, especially to Augustine as witness par excellence. It was Augustine who called the sacrament 'a visible word'; it was he who stated that the efficacy of the Word is evinced in the sacrament, not because it is spoken, but because it is believed. Looking closely, one notices that both testimonia originate from the same tractate and even the same paragraph of Augustine's Tractates on the Gospel of John. ${ }^{24}$ It appears that by 1535-1536, Calvin had read these and other treatises thoroughly, since he cites them frequently. For the Tractates on the Gospel of John, this applies to a remarkable degree later as well, for they still play a significant role even in Calvin's discussions with his Lutheran opponents Westphal (1557-1578) and Heshusius (1561). ${ }^{25}$

A little further on in chapter four, Augustine is again cited as a witness for the view that the sacraments of the Mosaic Law announced Christ (OS I, 123). ${ }^{26}$ Quite rightly

21.See, for Luther - apart from the indices that have meanwhile appeared in the Weimarer Ausgabe (henceforth: WA) -especially Delius (1984); for Melanchthon and Bucer especially the editions in CR and (for Bucer) in the series Martin Bucers Deutsche Schriften and Martini Buceri Opera Latina.

22.'Da quod iubes et iube quod vis'; this citation appears, for example in Conf. 10 $40 ; 10,45 ; 10,60$ and later also in De dono pers. 20, 53. As is well known, this expression aroused Pelagius's criticism and thus became a pivotal topic in the Pelagian controversy.

23.'Ipse [sc. Christus] inquit Ambrosius, os nostrum est per quod patri loquimur, oculus noster per quem patrem videmus, dextra nostra per quam nos patri offerimus.' Cf. De Isaac vel anima $8,75$.

24.OS I, 119 en 120: Tract. in loh Ev. 80, 3 ('the sacrament is a visible word'; 'the efficacy of the Word is illustrated not because the word is spoken but because the word is believed'). The relevant chapter of Augustine has continued to play a significant role in Protestant polemic. For Luther, see for example Zur Mühlen (1993:271-281).

25.See, for example Smits vol. II (1956-1958:188-197) and Chun Kim (2011:59-74, 99-120).

26.'Non enim aliud illic Augustinus voluit quam, quod alibi idem scribit: sacramenta mosaicae legis Christum praenunciasse...' Cf. Aug., Ep. 138, 1. did Augustine call the cross of Christ the source of our sacraments (OS I, 127). ${ }^{27}$ It was, after all, this Church Father who called the Eucharist the bond of love (vinculum caritatis) (OS I, 146), ${ }^{28}$ and who served as witness of the communion under both kinds (OS I, 151). ${ }^{29}$ As proof that the chalice was once kept from no one, Calvin refers besides Augustine - to a series of patristic authors: Eusebius, Cassiodorus, Chrysostom, Jerome, Tertullian, and (Pseudo-) Cyprian (OS I, 151-152).

It is in the chapter on false sacraments that Calvin especially opens his patristic arsenal, for it is here that he opposes the scholastics most extensively. Moreover, in the first edition of the Institutes, it is only here that he mentions Lombardus' Sententiae by name. Also the Decretum Gratiani is cited frequently and accurately in this chapter. Against the scholastics - rather unflatteringly referred to as 'fools', 'mockers', 'sophists', and 'drivellors' - Calvin places the witness of the Fathers directly below that of scripture. One passage among many may serve to illustrate this. When Calvin speaks about the scholastic notion of satisfaction (satisfactio), he first recognises that in the course of time the ancients (veteres) also no longer had a pure conception of this, although their understanding still by far surpassed that of the scholastics.

And when we must argue on the basis of the authority of the ancients [i.e., the Fathers], which ancients, good God, do these men thrust upon us? A good part of these authors from whom Lombard, their leader, has sewn together his patchworks, were collected from the insipid ravings of certain monks, which pass under the names Ambrose, Jerome, Augustine, and Chrysostom. As in the present argument, almost all his evidence is taken from Augustine's book De poenitentia, ${ }^{30}$ which was carelessly patched together by some rhapsodist from good and bad authors indiscriminately. Indeed, it bears the name of Augustine, but nobody of even mediocre learning would deign to acknowledge it as his. $(O S I, 199)^{31}$

One hears here the humanist critique on the (indeed) pseudoAugustinian treatise De vera et falsa poenitentia, criticism sounded loudly by Erasmus and also already voiced by Luther. ${ }^{32}$ This writing is, in terms of both style and content, not Augustinian, and therefore cannot serve as a witness.

27.'Quod [sc. Christ crucem] ... iure Augustinus sacramentorum nostrorum fontem vocavit.' The meaningful note in the margin reads: 'Saepe hoc apud Aug. legitur.' One can refer to for example Tract. in loh. Ev. 120, 2; s. 5, 3 and some En. in Ps.

28. With correct reference to Tract. in loh. Ev. 26.

29.With the reference given there.

30.The treatise meant is De vera et falsa poenitentia.

31.'Et si veterum autoritate pugnandum est, quos, Deus bone, veteres nobis obtrudunt? Bona pars eorum, quibus Lombardus, eorum coryphaeus, centones suos contexuit, ex insulsis quorundam monachorum deliriis, quae sub Ambrosii, Hieronymi, Augustini et Chrysostomi nomine feruntur, decerpta sunt. Ut in praesenti argumento, omnia fere sumit e libro Augustini de poenitentia, qui a rhapsodo aliquo inepte ex bonis pariter ac malis autoribus consarcinatus, Augustini quidem nomen praefert sed quem nemo vel mediocriter doctus, agnoscere pro quidem nomen praefert, sed quem nemo vel mediocriter doctus, agnoscere pro
suo

32.Both of them rightly indicated the pseudonymity of this writing which probably dated back to the 10th or 11th century, the first one in his edition of Augustine's Opera omnia (cf. Smits vol. I [1956-1958:190]), the second one already several Opera omnia (cf. Smits vol. I [1956-1958:190]), the second one already several
years before the Reformation year 1517 (cf. Kähler 1952:3ff.). On the possible origin and date of the writing, see for example Fantini (1954:200-209). 
Also in the remainder of his long discussion of the seven or, so Calvin knew, even 13 Roman sacraments, ${ }^{33}$ Augustine's writings are repeatedly called to witness. I note that it happens here, from Lombard and Gratianus. ${ }^{34}$ Against the scholastics of his own time, Calvin places his own sources: apart from the original references to Augustine, it also includes historical material from Platina, ${ }^{35}$ Cassiodorus, ${ }^{36}$ Theophylact, ${ }^{37}$ and others. Very relevant - and preserved in all subsequent editions of the Institution - is a reference to Cyprian in the matter of the ordinations: Cyprian holds firmly that the election of an office holder is not legally valid without the consent of all the people. ${ }^{38}$ This correct procedure Calvin adds, has been proven for those times by the historians as well (OS I, 214).

In the (also extensive) final chapter 'On Christian Freedom, Ecclesiastical Power, and Political Administration' there is hardly any patristic argumentation. Some historical information is said to be taken from Eusebius (OS I, 247). ${ }^{39}$ Conspicuous, however, is Calvin's speaking of the duty of magistrates to be moderate, with the concluding remark: 'as Augustine says' (OS I, 266). ${ }^{40}$ Calvin himself does not provide any reference, ${ }^{41}$ evidently because he considers it to be a more or less common known dictum. Already in his Commentary on Seneca's De Clementia, he refers to Augustine in this non-specific way, that is, without mentioning the exact source. ${ }^{42}$ The passage remained unaltered and the exact source unspecified even until the Institution's final edition (Inst. IV, 20, 12). ${ }^{43}$

\section{Interim conclusions}

On the basis of this brief analysis of the first Institution and the Letter to Francis I, it may be concluded that:

1. Already in 1535, Calvin shows a remarkable knowledge of the fathers. All in all, they are cited 118 times. Sometimes Calvin takes his quotes from secondary sources such as Peter Lombard and the Decretum Gratiani. It is also

33.Cf. OS 1, 205: the sacramentum ordinis has been divided into seven sacramentalia: one each for the ordination of the doorkeepers, the lectors, the exorcists, the acolytes, the subdeacons, and the priests. - For a very interesting and valuable discussion of Calvin's rejection of the sacraments of confirmation, confession, penance, and extreme unction, see Schützeichel (1980).

34.The parallels given by Barth (OS I, 205 ff.) and Battles (1986:309ff.) from, for example Thomas Aquinas are nothing more than simple parallels. They are not mentioned in the original edition. Nonetheless, these (possible) parallels appea early in his career and was influenced by them. Thomas is brought up only sometimes since the 1539 Institution.

35.Platina [or: Platyna, i.e. Bartolomeo Sacchi de Platina] historicus, Liber de vita Christi ac omnium pontificum.

36. His Historia tripartita, which included the church histories of Socrates, Sozomenus, and Theodoretus.

37. His commentary on 2 Thessalonians.

38.For possible sources, see Barth in OSI, 214 (but read Ep. 51, 8 instead of 58, 8). Cf. Battles ([1986] 1989:313).

39.'Vide Eusebium in histor. eccles.' As suggested by Barth, the real source will have been Cassiodorus.

40.'ut Augustinus loquitur.'

41.One does not find any reference either in OS I or in $\mathrm{CO}$ I.

42.Cf. Battles and Hugo (1969:42-43).

43.Most likely source is one of Augustine's letters (Ep. 153, 3; 138, 2; 130, 6). possible that he takes some testimonies from other reformers (e.g. Melanchthon, Luther, and Bucer). Above all, however, Calvin himself appears to go ad fontes.

2. His use of the fathers is mainly apologetic and polemical. On the one hand one reads his defence: we, 'evangelical' Christians, are no 'modernists'; on the other hand his polemic: the scholastic theology of the recentiores is wrong in its appeal to the patres. Apart from this main use, there is a positive constitutive element, in particular in Calvin's appeal to Augustine. What, in essence, a sacrament is, we learn from Augustine; the Eucharist is 'the bond of love' (vinculum charitatis); according to Augustine, the laying on of hands (impositio manuum) is nothing but prayer (oratio) (OS I, 169). In addition, Cyprian and, in particular, a number of church historians from the patristic age are quoted in order to demonstrate the church's former purity (and thus, its contemporary aberration);

3. Especially on his idea of a sacrament - which, in all probability has been defined in contrast to other protestant concepts (of Zwingli, of the Anabaptists in particular, also against Luther) already in the first Institution - Calvin's appeal to the fathers is most prominent.

\section{The disputation at Lausanne (1536)}

One sees these main features confirmed when analysing Calvin's subsequent writings. A fine example is already the disputation in the cathedral of Notre Dame in Lausanne (1-8 Oct. 1536). ${ }^{44}$ The dispute takes place at the instigation of the government of the Swiss city of Berne, and particularly deals with justification by faith alone and the Lord's Supper. Calvin maintains silence until the fifth day, but is then provoked by the remark that the 'evangelicals' dishonour 'les sainctz docteurs anciens.' In a sudden eruption of knowledge he cites - apart from a number of biblical texts - a whole range of patristic testimonies. Any dismissal of the fathers, so Calvin commences, would be 'not only audacious but also beyond measure arrogant.' However, 'we take the trouble to read them and use the help of their teaching (doctrine) when it serves and as occasion offers' (CO 9, 877). ${ }^{45}$ As a matter of fact, scripture excels all other testimonies, as is also clear from various biblical texts (CO 9, 877-879). This was already the opinion of Cyprian: he considered Christ's Word to be more important than the words of his predecessors. Calvin exactly indicates the place in Cyprian's writings: 'au 2. livre des epistres en lepistre $3^{\prime}$ [in the second book of his letters, in letter 3] $(\mathrm{CO} 9,879)$, actually the same place and within the same context as in his Letter to Francis I (OS I, 29). ${ }^{46}$ Subsequently, Calvin enters at length into the topic of the day, that is, the problem of the real presence of Christ in the Eucharist. He quotes an impressive series of testimonies to prove his

44.Still interesting is the vivid description in Doumergue (1902:214-218). Among the subsequent studies on this dispute see for example Bavaud (1956). Calvin's the subsequent studies on this dispute, see for example Bavaud (1956). Calvin's Lausanne'; a critical edition of the full texts in Piaget (1928).

45. '... quand mestier est et que l'occasion s'y addonne.'

46.'Pater erat (Cyprianus, Ep. 3. lib. 2.), qui censuit unum Christum audiendum esse, de quo dictum sit: ipsum audite, nec respiciendum, quid alii ante nos aut dixerint, aut fecerint, sed quid, qui primus omnium est, Christus, praeceperit. 
own point of view: Tertullian, Pseudo-Chrysostom, ${ }^{47}$ six times Augustine. ${ }^{48}$ Each time he does so with a remarkably exactness: 'Tertullian ... refuting the error of Marcion'; 'about the middle the eleventh homily' [of Pseudo-Chrysostom]; 'Augustine in Letter 23 near the end'; Augustine 'in his book against the Manichaean Adimantus, about the middle'; Augustine 'at the beginning of one of his homilies on the Gospel of St John, about the eighth or the ninth one, I cannot exactly recall which one'; et cetera. Evidently, Calvin knows these testimonies by heart while attaching a high value to them.

\section{Collection of testimonies?}

On the basis of the foregoing one may ask whether Calvin started a collection of testimonia already early in his career. Some scholars are of the opinion that this was indeed the case. ${ }^{49}$ In her dissertation, Zillenbiller even goes further: Calvin will have been dependent on the Florilegium of Martin Bucer (Zillenbiller 1993:94-100). In my opinion, such a dependence cannot be proven on the basis of a number of (more or less striking) parallels alone. Moreover, Bucer's Florilegium was only available in manuscript form, and we have no indications that Calvin was acquainted with it in $1536 .{ }^{50}$ It seems feasible however, that he himself started some or other collection, and he undoubtedly knew a considerable number of patristic citations by heart. This last feature is evident, for instance, from his recurring appeal to the 11th homily of Pseudo-Chrysostom. It seems quite probable as well in view of his recurrent references to Augustine: time and again the same appeal to the Tractates on the Gospel of John, particularly In Ioh. Ev. tract. LXXX (cf. Smits vol. II, 1956-1958:189-197); the same 12th chapter from Contra Adimantum (cf. Smits vol. II, 1956-1958:155); the same Letter 23 (in modern editions Ep. 98) in order to prove the famed Calvinian quodammodo ['in a certain way'] in the question of whether bread and wine are really the body and blood of Christ (cf. Smits vol. II, 1956-1958:180).

\section{Later writings}

The above considerations do not mean that Calvin contented himself to a (likely) collection of dicta probantia and did not read and reread his patristic sources. From his Institution

47.Again the 11th homily from the Opus imperfectum in Matthaeum, just as in the Letter to Francis I (OS I, 28; cf. n. 23 above), and with the addition: 'Whoever may be the author of that unfinished commentary on Matthew.' It is interesting to note that the discussion on its authorship is still going on: cf. chlatter (1988:364-375), who (369ff.) opts for a certain deacon Annianus of Celeda. See also the introduction to Van Banning (1988), and many other aspects in Mali (1991). Nevertheless, the question of identity remains open. What is sure is that, for centuries, the very influential author propagated Pelagian and Arian opinions. I see no evidence that Calvin was aware of this.

48. In one of these cases, Calvin notes that he quotes a writing which had erroneously been attributed to Augustine, namely the work De fide ad Petrum liber unus (in modern research attributed to Fulgentius of Ruspe, a follower of Augustine). Cf. CO 9, 881: 'Oultre au livre de fide ad Petrum Diaconum (combien quon doubte si cest de luy ou de quelque autre ancien) au chap. 19 ...

49.Thus, in particular, Todd (1964:99), who assumes that Calvin at the Lausanne disputation made use of a written document.

50.Cf. Bucer (1988:esp. xiv-xvi) for the stadia of its genesis. Moreover, this florilegium contained practical material, particularly on canon law. With Fraenkel (xii-xiii) one may suppose that Bucer compiled another florilegium with theological quotations may suppose that Bucer compiled another florilegium with theological quotations
from the fathers. This might have been the Unio dissidentium, which under the from the fathers. This might have been the Unio dissidentium, which under the
name of Hermannus Bodius was published in, for instance, 1527 in Cologne and name of Hermannus Bodius of 1539 , particularly the edition of 1543 , and probably even the final Latin one of 1559, a continued study of the Fathers appears to be sure. ${ }^{51}$ The same impression is provided by his disputes with Pighius, Westphal, Heshusius, Bolzec, and Servet. Against Pighius and the Lutherans his appeal is to Augustine in particular; the same goes for his 1551 public and impromptu answer to Bolzec; against Servet he particularly appeals to Irenaeus and Tertullian (see, in particular, Wright 2003:83-98, and Lane 2002:9-34). Although this last feature will be caused by Servet himself, it remains striking that, against the declared anti-trinitarian Michael Servet, Calvin does not mention Augustine's On the Trinity even once. Did he deem Augustine's work to be too speculative or, in any case, not relevant against this formidable opponent? In Calvin's ample Defensio orthodoxae fidei de sacra Trinitate of the year 1554 Augustine is mentioned explicitly only four times ${ }^{52}$ (and, to be clear, not on the doctrine of Divine Trinity, but on the question of whether it is permitted to take legal action against heretics). ${ }^{53}$

As a typical example of Calvin's use of the patristic sources, I briefly refer to his debate with Pighius. ${ }^{54}$ At the centre of Calvin's controversy with this Dutch theologian is the problem of free will and God's grace. Augustine is Pighius's crown witness and Calvin readily and quickly accepts the challenge. Even before the Frankfurt Book Fair of 1543 his answer is ready. Nearly every page of the printed book Defensio sanae et orthodoxae doctrinae de servitute et liberatione humani arbitrii adversus calumnias Alberti Pighii Campensis [A Defence of the sound and orthodox Doctrine of the Bondage and Liberation of the human Will against the Calumnies of Albertus Pighius from Kampen] contains references to the Church Father from North Africa. Much more than frequency, however, it is Calvin's specific method of citing that counts. The humanistically trained Calvin reproaches Pigghe with his old-fashioned method: he does not always quote Augustine from the original context, but makes use of florilegia. Moreover, by citing pseudo-Augustiniana he betrays his lack of eruditio. Most important in this context is what I would like to term 'Calvin's hermeneutical principle in reading Augustine'. According to Calvin, the Church Father should be read proceeding from his later writings. In other words, the anti-Pelagian works are key to Augustine's theology. Pighius flatly denies this: in the course of the years, the 'plane truth' (nuda veritas), the 'genuine and sound doctrine' (vera et sana doctrina) in Augustine's writings has diminished (cf. CO 6, 294). More than once one gets the impression that, in particular in the 16th century, this is a very essential difference in the dispute between

\section{See for this and the following Van Oort (1997:673-684).}

52.Cf. Smits vol. II (1956-1958:102-103). The work in its original edition in quarto counts 261 pages; a copy is in the library of Utrecht University.

53.All quotes fall within the book's section entitled 'An christianis iudicibus haereticos punire liceat', CO 9, 461-470.

54.See the dissertation of Melles (1973). The opposition mainly is between Pighius (1542) and Calvin's refutation in Defensio sanae et orthodoxae doctrinae de servitute humani arbitrii (1543), after nine years continued in his De aeterna predestinatione (1552). More on background, editions, and studies in: Peter and Gilmont, Bibliotheca Calviniana I (1991:122-125, 443-448). 
the Reformation theologians and their Roman-Catholic contemporaries..$^{55}$

From the foregoing one could get the impression that in essence, the 'patristic' Calvin is the 'Augustinian' Calvin. Indeed, Augustine is to Calvin, as he is to nearly every contemporary, the most important theological witness. ${ }^{56}$ Yet Calvin is acquainted with a whole range of patristic authors. He has a rather thorough knowledge and nearly always, a high appreciation of Chrysostom; ${ }^{57}$ Cyprian is important to his ecclesiology (see e.g. Zillenbiller 1993); Ambrose is an excellent witness (testis) to Calvin's idea of iustificatio as well as to his opinions on the relation between church and state and the communion under both kinds. ${ }^{58}$ In the course of the years, an impressively long series of 'patristic' authors has been quoted by Calvin: it runs from Irenaeus via Tertullian and Cyrill of Alexandra even to 'the last of the fathers': St Bernard. ${ }^{59}$

Did he have first-hand knowledge of all of them? Such seems to be impossible by human standards. However, a Christianhumanist of his calibre could certainly handle an impressive amount of patristic writings and, when necessary, would know to read them up again. ${ }^{60}$

\section{Use and misuse of the Fathers}

Some final notes on Calvin's use of the Fathers are in order. Indeed, he was using them: Calvin was in search of 'supporting authorities'. It may be possible to refer to his juristic background for this manner of argumentation. In any case, it was in accordance with the general method of theologising of his age.

Yet, Calvin more than once transcended this method. On the basis of his knowledge and appreciation of the fathers, he arrived at reformed renewal. I only mention here his appeal to the so-called 'Ambrosiaster' (i.e., the well-known commentary on the Pauline epistles which was erroneously attributed to Ambrose), ${ }^{61}$ in order to demonstrate that the

55.See for example Luther, WA 1, 224, 7-8; WA Tischrreden 1, 85, 12-13. Already in Erasmus's œuvre, one encounters the reproach that the later Augustin would have spoken 'excessively' (excessive) and, for this reason, would have les authority. In the 17th century, the same reproach was heard in the controversies around Jansenius and the Jansenists. At stake here is the (still essential) question of the 'real' and 'entire' Augustine; in his Retractationes, Augustine himself reread (and evaluated) his writings from his later anti-Pelagian point of view.

56. Especially on the eve of the Reformation, and particularly on the basis of Erasmus's edition of his work, there is also a special interest in Jerome, for instance as an example of eruditio and pietas. See for example Hasse (1993:33-53), and also Hamm (1990:127-235). - The enormous interest of the Reformation era in Augustine does not need further illustration here, because it is tangible nearly Augustine does not need further illustration here, because it is tangible nearly
everywhere. It is apparent in the various florilegia; see for example Lane (1993: 69-95).

57.Cf. Walchenbach (1974) and Ganoczy and Müller (1981). Preserved for posterity is Calvin's highly interesting introduction to his (planned) translation of sermons of Chrysostom; see CO 9, 831-838.

58.See further Van Oort ([1997] 2001:688-689) and, in particular, Mooi (1965: 217-222).

59.Cf. Van Oort ([1997] 2001:passim) and, in particular, Mooi (1965:passim). On Calvin's notable recognition of Bernard, also Lane (1981) and Raitt (1981).

60 .For the humanists' knowledge of the Fathers, see for instance the contributions in Backus (1997).

61.It has often been contended (also by Mooi 1965) that this sobriquet was given by Erasmus. However, this opinion appears to be incorrect. In 1572 , the Jesuit $F$.
Ancient Church knew the office of lay elders (seniores), a position which was actually adopted from the Jewish synagogue. ${ }^{62}$ Reference should also be made to his fine and charming booklet that was first published in 1542: La forme des prieres et chantz ecclesiastiques, avec la maniere d'adminstrer les Sacremens, \& consacrer le Mariage:selon la coustume de l'Eglise ancienne [The Form of Prayers and Ecclesiastical Chants with the Manner of Administering the Sacraments and Solemnizing Marriage according to the Custom of the Ancient Church] (cf. OS 2, 11-58). The phrase 'according to the Custom of the Ancient Church' is programmatic and, as far I can see, still deserves a thoroughgoing investigation as to its factual patristic basis. Does the 'liturgical Calvin' not coincide with the 'patristic Calvin' to a considerable extent?

Apart from all these positive features of Calvin's use of the Fathers, there was also a certain misuse. Calvin's forte in the discussions with his opponents were, without a doubt, his ability to read the Fathers from their original context and, generally speaking, according to their original meaning. Now and then, however, when it suits his case better, he omits certain facts. Cyprian is deemed by Calvin to be a fine witness to central parts of his ecclesiology, but he does not mention that this Church Father believed the Eucharist to be a sacrifice. ${ }^{63}$ His appeal to Chrysostom is rather selective. ${ }^{64}$ Jerome's view of the Lord's Supper is considered to be unclear, but Calvin nevertheless appeals to it in his disputes with Heshusius and Westphal (cf. Mooi 1965:226-227). In quoting Bernardus - with whom he rightly considers himself to be in accord on the issues of grace, the bondage of the will, and justification - he sometimes omits essential passages. ${ }^{65}$ Particularly his reading of the ancient church historians and the acts of the councils is rather selective. In this special field of knowledge, Calvin makes some striking (and even until today influential) mistakes, for instance in his opinion that the Council of Nicaea was presided over by Athanasius (Inst. IV $, 7,1) .{ }^{66}$ Generally speaking one may say that Calvin (like the great majority of his contemporaries) was a 'practical

Turrianus seems to have been the first to cast doubt on Ambrose's authorship; the name Ambrosiaster for the first time turned up in the edition of Ambrose's works by the Maurists which appeared in the years 1686-1690. Thus the opinion of Hoven (1969:169-174). Similar opinions have been expressed since then. Recently, however, Krans (2013:274-281) has opted for Franciscus Lucas Brugensis (Françoi Lucas from Bruges in the Southern Netherlands, present-day Belgium). His reference is to several passages in Brugensis (1580). - Rather recently, an attempt to identify 'Ambrosiaster' with Maximus of Turin has been refuted by the Maximus' specialist Merkt (1996:19-33). In actual fact, his identity remains a mystery.

62. One finds the reference to the Pauline commentary of 'Ambrosiaster' for the first time in the 1543 edition of the Institution $(C O 1,650)$ and, in more elaborated form in the 1559 Inst. (CO 2, 897). See also Calvin's Comm. in utramque ep. ad Tim. on $1 \mathrm{Tim}$. 5 (CO 52, 315-316). On these lay elders, see for example Frend (1961:280284). The fact that also Ambrosiaster was acquainted with the institution of lay elders (Ad Tim. I, 5, 2: 'Unde et synagoga, et postea ecclesia seniores habuit, elders (Ad Tim. I, 5, 2: 'Unde et synagoga, et postea ecclesia seniores habuit,
quorum sine consilio nihil agebatur in ecclesia') may function as one of the many
proofs of direct Jewish influences on Christian institutions. Calvin wants to go back to a genuine Jewish-Christian institution.

63.Cf. Cyprian, Ep. 63, 14 on the Eucharist as 'sacrificium verum et plenum'. Calvin knew the contents of this letter (formerly nr. 3 in Lib. II. epist. in Erasmus's edition, Basel 1520).

64.Cf. Walchenbach (1974:172-190): 'Examples of Calvin's Procedure as Applied to John Chrysostom.' As is well known, Calvin had particular difficulties with Chrysostom's views of free will, but he is able to mention several reasons for Chrysostom's opinions in this regard. Cf. Mooi (1965:274-275).

65.Cf. Raitt (1981:117-118): from this incomplete 'quotation' in Inst. III,24,4 it may be concluded that, in Calvin's opinion, Bernard takes his mysticism too far.

66.For these and other mistakes, see Mooi (1965:339-343). 
historian': he mentions and makes use of those facts which suit his case. ${ }^{67}$

Notwithstanding these (from our modern perspective) evident shortcomings, he was doubtlessly a great patristic scholar. In comparison with his contemporaries, his knowledge was in many respects unique. ${ }^{68}$ This special patristic knowledge gave his theology its special hallmark. For his many followers worldwide, this may still mean that the patristic element genuinely belongs to Calvinist theology and can preserve it from plain and unhistorical Protestantism. The testimonium patrum [testimony of the fathers] links the Reformation with the church's catholic tradition through the ages. ${ }^{69}$

\section{Acknowledgements Competing interests}

The author declares that he has no financial or personal relationships which may have inappropriately influenced him in writing this article.

\section{References}

Awad, N.G., 2010, 'The influence of John Chrysostom's hermeneutics on John Calvin's exegetical approach to Paul's Epistle to the Romans', Scottish Journal of Theology 63, 414-436. http://dx.doi.org/10.1017/S0036930610000499

Baars, A., 2004, Om Gods verhevenheid en nabijheid:de drie-eenheid bij Calvijn, J.H. Kok, Kampen.

Backus, I., 1991, 'Calvin's judgment of Eusebius of Caesarea: An analysis', Sixteenth Century Journal 22, 419-437.

Backus, I. (ed.), 1997, The reception of the Church Fathers in the West: From the Carolingians to the Maurists, Brill, Leiden.

Battles, F.L., 1966, 'The sources of Calvin's Seneca commentary', in G.E. Duffield (ed.), John Calvin, pp. 38-66, Sutton Courtenay Press, Appleford. (Also in Battles 1996:65-89).

Battles, F.L., [1986] 1989, John Calvin, Institutes of the Christian Religion, rev. edn. M.H. Rienstra (ed.), Eerdmans, Grand Rapids.

Battles, F.L., 1996, Interpreting John Calvin, Eerdmans, Grand Rapids, MI.

Battles, F.L. \& Hugo, A.M., 1969, Calvin's commentary on Seneca's De Clementia, Brill, Leiden.

Bavaud, G., 1956, La dispute de Lausanne (1536): Une étappe de l'évolution doctrinale des réformateurs romands, Editions Universitaires Fribourg, Fribourg.

Boisset, J., 1988, 'La Réforme et les Pères de l'Église. Les références patristiques dans l'Institution de la Religion Chrétienne de Jean Calvin', in A. Mandouze \& J. Fouilheron (eds.), Migne et le renouveau des études patristiques, pp. 39-51, Beauchesne, Paris.

Brugensis, F.L., 1580, Notationes in Sacra Biblia, Plantin, Antwerp.

Bucer, M., 1988, Martin Bucer et Matthew Parker, Florilegium Patristicum. Edition critique publié par Pierre Fraenkel, Martini Buceri Opera Latina III, Brill, Leiden.

Calvin, J., 1543, Defensio sanae et orthodoxae doctrinae de servitute humani arbitrii, loannem Gerardum, Genevae.

Calvin, J., 1552, De aeterna predestinatione, Crespin, Genevae.

Chung-Kim, E., 2011, Inventing authority: The use of the Church Fathers in Reformation debates over the Eucharist, Baylor University Press, Waco, TX.

67.Cf. also Fischer (1986:esp. 123). Cf. Backus (1991:esp. 425, 427, 436-437) Examples of Calvin's misuse of Tertullian in Lane (2002).

68.Cf. Holl (1928:282): 'Ohne Übertreibung darf man ihn [sc. Calvin] den gelehrtesten Theologen seiner Epoche nennen. Er beherrschte die Kirchenväter wie keiner seine Zeitgenossen. Und das war kein totes Wissen.'

69.For Calvin's sense of being 'catholic', see, for example, Inst. IV, 1, 2 and Catechismus ecclesiae Genevensis 97 (OS II, 89): 'Quid sibi vult epithethon catholicae vel universalis? - Eo docemur, sicut unum est fidelium omnium caput, ita omnes in unum corpus coalescere oportere, ut una sit ecclesia per totum orbem diffusa: non plures'. Cf. e.g. Confessio Scotica 17; Confessio Helvetica posterior 17; Confessio Belgica 27. Cf. e.g. Melanchthon, in his rejection of his opponents' use of the designation 'Lutheran Church' (CR 24, 399): 'Aliud est dici Catholicum, aliud revera esse Catholicum. Ille vere nominatur Catholicus qui amplectitur doctrinam, quae est Ecclesiae vere Catholicae, id est, quae habet testimonium omni tempore, omnibus aetatibus, quod sic sentiat ut Prophetae et Apostoli docuerunt. (...) Omnes debemus esse Catholici ...'
Corpus iuris canonici (ed.), [1879] 1959, Lipsiensis secunda [...] instruxit Aemilius Friedberg, I, Decretum Magistri Gratiani, Ex officina Berhardi Tauchnitz, Lipsiae.

Dankbaar, W.F., 1941, De sacramentsleer van Calvijn, H.J. Paris, Amsterdam.

Delius, H-U., 1984, Augustin als Quelle Luthers: Eine Materialsammlung, Evangelische Verlagsanstalt, Berlin.

Doumergue, É., 1902, Jean Calvin. Les hommes et les choses de son temps, II, Georges, Bridel et Cie., Lausanne.

Fantini, C., 1954, 'Il trattato ps.-agostiniano “De vera et falsa poenitentia”', Ricerche di Storia Religiosa 1, 200-209.

Fischer, D., 1986, 'L'histoire de l'Eglise dans la pensée de Calvin', Archiv für Reformationsgeschichte 77, 79-125.

Frend, W.H.C., 1961, 'The Seniores Laici in the origins of the Church in North Africa' Journal of Theological Studies 12, 280-284. http://dx.doi.org/10.1093/jts/ XII. 2.280

Ganoczy, A. \& Müller, K., 1981, Calvins handschriftliche Annotationen zu Chrysostomus: Ein Beitrag zur Hermeneutik Calvins, Franz Steiner Verlag, Wiesbaden.

Hamm, B., 1990, 'Hieronymus-Begeisterung und Augustinismus vor der Reformation', in K. Hagen (ed.), Augustine, the harvest, and theology (1300-1650), pp. 127-235, Brill, Leiden.

Hasse, H-P., 1993, 'Ambrosius Blarer liest Hieronymus', in L. Grane, A. Schindler \& M. Wriedt (eds.) Auctoritas Patrum: Contributions on the Reception of the Church Fathers in the 15th and 16th Century, pp. 33-53, Philipp von Zabern Verlag, Mainz.

Hazlett, I.P., 1991, 'Calvin's Latin Preface to his proposed French translation of Chrysostom's Homilies: Translation and commentary', in J. Kirk (ed.), Humanism and reform: The Church in Europe, England and Scotland, 1400-1643, pp. 129-150, Blackwell Publishers, Oxford. (Studies in Church History, subsidia, 8).

Holl, K., 1928, 'Johannes Calvin (Rede bei der Calvinfeier der Universität Berlin am 10. Juli 1909', in K. Holl (ed.), Gesammelte Aufsätze zur Kirchengeschichte, III, Der Westen, pp. 254-284, J.C.B. Mohr, Tübingen.

Hoven, R., 1969, 'Notes sur Érasme et les auteurs anciens', L'Antiquité classique 38, 169-174.

Hugo, A.M., 1957, Calvijn en Seneca. Een inleidende studie van Calvijns Commentaar op Seneca, anno 1532, Wolters, Groningen-Djakarta.

Kähler, E., 1952, Karlstadt und Augustin, Max Niemeyer, Halle.

Krans, J., 2013, 'Who coined the name "Ambrosiaster"?', in J. Krans, L.J. Lietaert Peerbolte \& P.-B. Smit (eds.), Paul, John, and Apocalyptic Eschatology, pp. 274281, Brill, Leiden and Boston, MA.

Lane, A.N.S., 1976, 'Calvin's sources of St. Bernard', Archiv für Reformationsgeschichte 67, 253-283.

Lane, A.N.S., 1981, 'Calvin's use of the Fathers and the Medievals', Calvin Theological Journal 16, 149-205. (Revised and updated in Lane (1999:15-66, 261-287)).

Lane, A.N.S., 1993, 'Justification in sixteenth-century Patristic anthologies', in L. Grane, A. Schindler, \& M. Wriedt. (eds.), Auctoritas Patrum: Contributions on the Reception of the Church Fathers in the 15th and 16th Century, pp. 69-95, Philipp von Zabern Verlag, Mainz.

Lane, A.N.S., 1999, John Calvin: Student of the Church Fathers, T \& T Clark, Edinburgh.

Lane, A.N.S., 2002, 'Tertullianus totus noster? Calvin's use of Tertullian', Reformation \& Renaissance Review 4, 9-34.

Lange van Ravenswaaij, J.M.J., 1990, Augustinus totus noster: Das Augustinverständnis bei Johannes Calvin, Vandenhoeck \& Ruprecht, Göttingen.

Lombardus: Magistri Petri Lombardi Sententiae in IV libris distinctae, 1971-1981, ed. 3a, Collegii S. Bonaventurae Ad Claras Aquas, Grottaferrata (Rome).

Mali, F., 1991, Das „Opus Imperfectum in Matthaeum” sein Verhältnis zu Matthäus Kommentare von Origenes und Hieronymus, Tyrolia, Innsbruck. (Innsbrucker Kommentare von Origen
theologische Studien, 34).

McNeill, J.T. \& Battles, F.L., 1960, Calvin: Institutes of the Christian Religion, Westminster Press, Philadelphia, PA.

Meijering, E.P., 1980, Calvin wider die Neugierde: Ein Beitrag zum Vergleich zwischen reformatorischem und patristischem Denken, De Graaf, Nieuwkoop.

Melles, G., 1973, Albertus Pighius en zijn strijd met Calvijn over het liberum arbitrium, Kok, Kampen.

Merkt, A., 1996, 'Wer war der Ambrosiaster?', Wissenschaft und Weisheit 59, 19-33.

Mooi, R.J., 1965, Het kerk- en dogmahistorisch element in de werken van Johannes Calvijn, H. Veenman \& zonen, Wageningen [Diss. Utrecht 1965].

Obendiek, H., 1936, 'Die Institutio Calvins als "Confessio" und "Apologie"', in E. Wolf (ed.), Theologische Aufsätze Karl Barth zum 50. Geburtstag, pp. 417-431, C. Kaiser, München.

Old, H.O., 1975, The patristic roots of reformed worship, Theologischer Verlag, Zürich.

Peter, R. (†) \& Gilmont, J-F., 1991, Bibliotheca Calviniana: Les œuvres de Jean Calvin publiées au XVle siècle, I, Écrits théologiques, littéraires et juridiques 1532-1554, Librairie Droz, Genève.

Piaget, A., 1928, Les actes de la dispute de Lausanne 1536, Secrétariat de l'Université, Neuchâtel.

Pighius, A., 1542, De libero hominis arbitrio et divina gratia, Melchior Novesianus, Coloniae.

Polman, P., 1932, L'élément historique dans la controverse religieuse du XVI siècle, J. Duculot, Gembloux.

Raitt, J., 1981, 'Calvin's use of Bernard of Clairvaux', Archiv für Reformationsgeschichte 72, 98-121. 
Schlatter, F.W., 1988, 'The author of the Opus Imperfectum in Matthaeum', Vigiliae Christianae 42, 364-375. http://dx.doi.org/10.2307/1584284

Schützeichel, H., 1980, Katholische Calvin-Studien, Paulinus-Verlag, Trier. (Trierer Theologische Studien, 42).

Seebach, L., 2011, 'Augustin und Calvin', in M. Basse (ed.), Calvin und seine Wirkungsgeschichte, pp. 75-98, Lit Verlag, Berlin and Münster. (Dortmunde Beiträge zu Theologie und Religionspädagogik, 8).

Smits, L., 1956-1958, Saint Augustin dans l'œeuvre de Jean Calvin, 2 vols., Van Gorcum, Assen.

Todd, W.N., 1964, 'The function of the patristic writings in the thought of John Calvin', ThD thesis, Union Theological Seminary, New York, NY.

Van Banning, J. (ed.), 1988, Opus imperfectum in Matthaeum, CCL 87B, Brepols, Turnhout.

Van Oort, J., 1991, Jerusalem and Babylon: A study of Augustine's City of God and the sources of his doctrine of the two cities, Brill, Leiden. (Paperback ed. Brill, LeidenBoston, 2013).
Van Oort, J., 1992, 'Calvijn en Augustinus', Nederlands Archief voor Kerkgeschiedenis $72,92-103$.

Van Oort, J., [1997] 2001, 'John Calvin and the Church Fathers', in I. Backus (ed.) The reception of the Church Fathers in the West: From the Carolingians to the Maurists, pp. 661-700, Brill, Leiden and Boston, MA.

Walchenbach, J.R., 1974, 'John Calvin as biblical commentator: An investigation into Calvin's use of John Chrysostom as an Exegetical tutor', PhD thesis, University of Pittsburgh.

Wright, D.F., 2003, 'Calvin and Servetus in dispute over Irenaeus', Perichoresis 1, 83-98.

Zillenbiller, A., 1993, Die Einheit der katholischen Kirche: Calvins Cyprianrezeption in seinen ekklesiologischen Schriften, Philipp von Zabern, Mainz.

Zur Mühlen, K-H., 1993, 'Die Rezeption von Augustins “Tractatus in Joannem 80, 3" im Werk Martin Luthers', in L. Grane, A. Schindler \& M. Wriedt (eds.), Auctoritas Patrum: Contributions on the reception of the Church Fathers in the 15th and 16th Century, pp. 271-281, Philipp von Zabern Verlag, Mainz. 